\title{
Seasonal Variation in the Dietary Preferences OF THE MONTANE VOLE, MICROTUS MONTANUS
}

\author{
AELITA J. PINTER $\bullet$ DEPARTMENT OF BIOLOGICAL SCIENCES \\ UNIVERSITY OF NEW ORLEANS $\bullet$ NEW ORLEANS \\ NORMAN C. NEGUS • PATRICIA J. BERGER \\ BIOLOGY DEPARTMENT • UNIVERSITY OF UTAH \\ SALT LAKE CITY
}

\section{$\checkmark$ OBJECTIVES}

Seasonal variation in food selection has been documented in several species on voles (Rothestein and Tamarin 1977, Cole and Batzli 1979, Goldberg et al. 1980) with considerable implications for winter survival and population dynamics. In Microtus montanus a similar link may exist between growth, maturation, longevity, and population dynamics on the one hand and dietary composition on the other (e.g., Pinter and Negus 1965, Berger et al. 1981, Pinter 1988, Berger et al. 1992, Negus et al. 1992). Consequently, we undertook a study to investigate in detail the utilization of plant resources by the montane vole, Microtus montanus. The objectives of this project are twofold: (1) to identify the plant species that constitute the diet in natural populations of $M$. montanus and (2) to determine seasonal food preferences in relation to the availability of plant species and to the age, sex and cohorts of the montane vole.

\section{$\checkmark \quad$ METHODS}

Two field sites, approximately $160 \mathrm{~km}$ apart, in northwestern Wyoming, were used for this study. One study area is within Grand Teton National Park (GTNP site). The other is located along the upper Green River (GR site), near the boundary of the
Bridger-Teton National Forest, Sublette County, Wyoming. Both sites are mesic montane meadows at elevations ranging from 2057 to $2134 \mathrm{~m}$. Both sites are quite similar in floristic composition, consisting of a mixture of grasses, sedges, and forbs.

Voles were live trapped at both sites in spring (May), summer (July-August) and fall (October-November). Winter trapping (monthly sampling, November-March) was accomplished only at the GR site since winter trapping necessitates the use of 5 gallon plastic buckets with tall marker poles and flags. These buckets and poles were established in the late fall before permanent winter snow cover had arrived. Since these structures are highly visible from considerable distances, they would be quite undesirable at sites within Grand Teton National Park. However, we are confident that the winter data can be extrapolated from the GR site to the GTNP site since the two areas have very similar floristic composition and cohort dynamics (Negus et al. 1992). Initial processing of GTNP field samples was carried out at the UW-NPS Research Center laboratory. Livetrapped animals were sacrificed, and stomach and fecal samples collected. Several slides were prepared from each plant collected. Microscopic identification of plants from stomach and fecal samples and subsequent statistical analysis is being undertaken at the University of Utah, Department of Biology. 


\section{$\checkmark \quad$ RESUlTS}

Apparently relatively few species of monocotyledons form the bulk of the summer diet for the montane vole. We are in the process of determining the relative importance of these species in the diet. The following species appear to be extensively utilized whenever they are available as plants: Stipa sp., Agropyron cristatum, Poa pratensis, Phelum pratense, Dactylis glomerata, Deschampsia caespitosa, Carex sp., Trisetum wolfii, Festuca sp. Other species that are utilized at lower frequency include the following: Agropyron intermedium, Echinochloa colonum, Hordeum jubatum, Alopecurus sp. With few exceptions, as grasses and sedges approach vegetative maturity just prior to flowering, their use of food resources by montane voles decreases. Doubtless this is due in part to the increasingly ligneous nature of the stems as flowering and fruiting is approached. The time needed to attain vegetative maturity varies among species of plants. Consequently, some plants are being consumed for longer periods of their vegetative growth than others. For example, lignification of stems is relatively slow in Poa pratensis and Festuca pratensis, which perhaps accounts for the fact that these grasses are preferential food items for many herbivorous mammals. On the other hand, both Dactylis glomerata and Trisetum wolfii are consumed by voles at high frequency while the plants are young. However, the frequency of use decreases rapidly since these plants rather quickly develop ligneous stems.

In our fall-winter-spring sampling under the snow, we found that in late fall (November) the utilization of dicotyledons increased markedly. Dicotyledonous plants remained a dominant part of the diet until meltoff in April. We have not as yet determined why the shift to dicotyledons occurred when it did. We would have expected such a shift much earlier (Sept-early Oct.) coincident with the senescence of all monocotyledons.

\section{$-\quad$ CONCLUSIONS}

As this study progresses, it becomes increasingly apparent that the montane vole forages preferentially on plant species based on more than one criterion. To a considerable degree the total array of species consumed is based on nutritional value. However, at any given time in the growing season, voles seem to preferentially consume plants that are most palatable. This then becomes an optimal foraging strategy since more energy is doubtless required to process a highly ligneous grass stem compared to a more succulent one. Young voles appear to be less discriminating in their consumption of various species, suggesting that, from an energetic standpoint, experience may increase foraging efficiency.

\section{- ACKNOWLEDGEMENTS}

We gratefully acknowledge the availability of the facilities and the help of the staff at the University of Wyoming-National Park Service Research Center without which it would have been impossible to accomplish this work.

\section{$\checkmark \quad$ Literature Cited}

Berger, P.J., N.C. Negus, A.J. Pinter and T.R. Nagy. 1992. The effect of maternal 6MBOA on growth and development of offspring in Microtus montanus. Canadian J. Zoology 70:518-522.

Berger, P.J., N.C. Negus, E.H. Sanders, and P.H. Gardner. 1981. Chemical triggering of reproduction in Microtus montanus. Science 214:69-70.

Cole, F.R., and G.O. Batzli. 1979. Nutrition and population dynamics of the prairie vole, Microtus ochrogaster, in central Illinois. J. Anim. Ecol., 48:455-470.

Goldberg, M., N.R. Tabroff, and R.H. Tamarin. 1980. Nutrient variation in beach grass in relation to beach vole feeding. Ecology 61:1029-1033.

Negus, N.C., P.J. Berger, and A.J. Pinter. 1992. Phenotypic plasticity of the montane vole, Microtus montanus in unpredictable environments. Canadian J. Zool. 70:21212124. 
Pinter, A.J. 1988. Multiannual fluctuations in precipitation and population dynamics of the montane vole, Microtus montanus. Canadian J. Zool. 66:2128-2132.

Pinter, A.J. and N.C. Negus. 1965. Effects of nutrition and photoperiod on reproductive physiology of Microtus montanus. Amer. J. Physiol. 208:633-638.
Rothestein, B. and R.H. Tamarin. 1977. Feeding behavior of the insular beach vole, Microtus breweri. J. Mammal. 58:84-85. 